\title{
Secretion of angiogenic activity by placental tissues of cows at several stages of gestation
}

\author{
L. P. Reynolds and D. A. Redmer \\ Department of Animal and Range Sciences, North Dakota State University, Fargo, \\ North Dakota 58105, U.S.A.
}

\begin{abstract}
Summary. Samples of maternal and fetal placental tissues were obtained from cows on Days $100(\mathrm{~N}=4), 150(\mathrm{~N}=5), 200(\mathrm{~N}=6)$ and $250(\mathrm{~N}=6)$ of gestation and incubated for $24 \mathrm{~h}$. Conditioned media from caruncular explants were mitogenic for bovine aortic endothelial cells (BAEC) on all days of gestation. Media from intercaruncular endometrium were stimulatory for proliferation of BAEC on Day 100 but inhibitory on Days 150, 200 and 250. Media from cotyledonary and intercotyledonary tissues inhibited proliferation of BAEC on all days. Caruncular-conditioned media stimulated migration of BAEC on Days 150, 200 and 250. Cotyledonary-conditioned media inhibited migration of BAEC on all days. Effects of media from intercaruncular and intercotyledonary tissues on migration of BAEC varied with stage of gestation. Angiogenic activity of media from caruncular (all stages) and intercaruncular (Day 100) tissues appeared to have an $M_{\mathrm{r}}>100000$. In cows, therefore, the maternal placentome (caruncle) appears to be the primary source of placental angiogenic activity throughout gestation. The fetal placentome (cotyledon) secretes activity which inhibits two major components of angiogenesis (proliferation and migration of endothelial cells) throughout gestation. Intercaruncular and intercotyledonary tissues may modulate placental angiogenesis throughout gestation. Placental vascular development in the cow is therefore probably controlled by an interaction between stimulatory and inhibitory factors produced by the placenta itself.
\end{abstract}

Keywords: angiogenic factor; placenta; gestation; cow

\section{Introduction}

Mossman (1937) defined the mammalian placenta as "an apposition or fusion of the fetal membranes to the uterine mucosa for physiological exchange". Previous work has shown that size of the placental blood supply is a primary determinant of the rate of physiological exchange between the maternal and fetal systems (Bell et al., 1986; Reynolds et al., 1986; Reynolds \& Ferrell, 1987). Conditions associated with reduced rate of fetal growth (e.g. maternal genotype, increased numbers of fetuses, maternal nutrient deprivation, environmental heat stress) are also associated with reduced rates of placental blood flow and fetal oxygen and nutrient uptakes (Wootton et al., 1977; Morriss et al., 1980; Reynolds et al., 1985a, b; Ferrell \& Reynolds, 1987). Reduced rate of fetal growth can lead to decreased birth weight, which has a major impact on neonatal survival and growth (Record et al., 1952; Anderson et al., 1978; Fahmy et al., 1978; Huffman et al., 1985). Factors which influence placental vascular development are therefore likely to play an important role in fetal growth and development and, ultimately, in growth and survival of the neonate.

When tissues were obtained from cows at mid-gestation, only maternal and not fetal placental tissues secreted angiogenic activity (Reynolds et al., 1987b). This observation led to the proposal that the maternal placenta may direct placental vascularization. However, fetal tissues may modulate 
placental angiogenesis, and the site of production of placental angiogenic factors may change with stage of gestation. Some evidence exists in support of these proposals, since angiogenic activity has been found only in the maternal portion (decidua) and not the fetal portion of the human placenta at mid-gestation (Fuchs et al., 1985), whereas others have reported angiogenic activity in human fetal membranes (amnio-chorion) and placental cotyledons at term (Burgos, 1983). In studying placental tissues of ewes, we found that maternal endometrium secreted angiogenic activity early in gestation, but only fetal cotyledonary tissue secreted angiogenic activity late in gestation (Reynolds et al., 1987a; unpublished observations).

The purposes of this study were to determine which placental tissues secrete angiogenic activity, something of the nature of this activity, and whether the site of production or the type of activity change with the stage of gestation.

\section{Materials and Methods}

Samples $(\sim 2 \mathrm{~g})$ of maternal (caruncular) and fetal (cotyledonary) portions of the placentome, intercaruncular uterine endometrium and intercotyledonary chorioallantois were obtained from cows on approximately Days $100(103 \pm 0 \cdot 7$, $\mathrm{N}=4), 150(151 \pm 0 \cdot 5, \mathrm{~N}=5), 200(200 \pm 1 \cdot 2, \mathrm{~N}=6)$ and $250(250 \pm 0 \cdot 5, \mathrm{~N}=6)$ of gestation. Minced explants $(141 \pm 7.9 \mathrm{mg}$ ) of each tissue were incubated as described previously (Reynolds et al., 1987b). To ensure relatively pure preparations of maternal and fetal placentomal tissues, contaminating tissue which was visible during mincing was removed. In addition, in a previous study (Reynolds et al., 1987b), no contaminating tissue was observed in maternal or fetal placentomal tissues prepared as in the present study and then observed in histological sections under light microscopy at $\times 250-400$. Explants were incubated in explant medium (Eagle's Minimal Essential Medium supplemented with dextrose, MEM non-essential amino acids, bovine pancreatic insulin, and antibiotic-antimycotic solution, $\mathrm{pH} 7.3)$ under $5 \% \mathrm{CO}_{2}-95 \%$ air in a Dubnoff shaking water bath $\left(30 \mathrm{cycles} / \mathrm{min}, 37^{\circ} \mathrm{C}\right)$ for $24 \mathrm{~h}$. After incubation, conditioned explant media were collected and stored at $-80^{\circ} \mathrm{C}$ until assayed for angiogenic activity.

Media conditioned by placental tissues were assayed for effects on proliferation and migration of bovine aortic endothelial cells (BAEC) by using procedures previously described by Reynolds et al. (1987b). For the proliferation assay, BAEC were preincubated for $24 \mathrm{~h}$ in 24 -well plates $\left(20 \times 10^{3}\right.$ cells/well) in medium containing $20 \%$ serum. After preincubation, medium was changed to serum-free medium containing $27 \%$ unconditioned (control, 3 wells/ plate) or $27 \%$ conditioned ( 3 wells/tissue) explant medium. The number of BAEC in each well was determined $72 \mathrm{~h}$ later by using a Coulter counter. For the migration assay, 48-well microchemotaxis chambers were used. The bottom portion of each well contained unconditioned explant medium (control, 4 wells/chamber) or unconditioned medium containing $20 \%$ conditioned explant medium ( 4 wells/tissue). The top portion of each well contained $65 \times 10^{3}$ BAEC in unconditioned explant medium. After incubation, the number of migrated BAEC was determined for each well by using a computerized image analysis system (Image Technology Corporation, Deer Park, NY) with a Microphot-FX upright microscope (Nikon, Tokyo). Conditioned media were also evaluated for their abilities to stimulate proliferation of BALB/3T3 cells (cell line CCL 163; American Type Culture Collection, Rockville, MD). Procedures used for the 3 T3 proliferation assay were identical to those used for the BAEC proliferation assay.

To determine approximate molecular weights of angiogenic activities, pools of conditioned media from caruncular tissues at each stage of gestation and also from intercaruncular endometrium at Day 100 were made. Each pool contained conditioned media from 46 cows. A sample $(2 \mathrm{ml})$ of each of these pools was subjected to ultrafiltration as described by Reynolds et al. (1987b) to obtain fractions of $M_{\mathrm{r}}\left(\times 10^{3}\right)<10,>10,<30,>30,<100$ and $>100$. These molecular weight range fractions were utilized in the BAEC proliferation assay ( 3 wells/fraction).

Data were analysed statistically by using least-squares analysis of variance, with effects of stage of gestation, tissue and stage $\times$ tissue interaction included in the model (SAS, 1985). When the F-test was significant $(P<0.05)$, differences between specific means were evaluated by using Bonferroni's $t$ test (Kirk, 1968). In addition, means for individual tissues were compared with control (unconditioned media) values by $t$ test (Steel \& Torrie, 1960). Data are reported as means \pm s.e.m.

\section{Results}

Effects of explant-conditioned media on proliferation of BAEC varied across stage of gestation $(P<0 \cdot 10)$ and among tissues $(P<0.01)$, and a stage of gestation $\times$ tissue interaction $(P<0.01)$ also was observed (Fig. 1). Media conditioned by caruncular explants stimulated $(P<0.01)$ proliferation of BAEC compared with unconditioned media, and this mitogenic activity did not change with stage of gestation (Fig. 1). Conditioned media from intercaruncular endometrium stimulated $(P<0 \cdot 10)$ proliferation of BAEC at Day 100 but inhibited $(P<0.01)$ proliferation of 


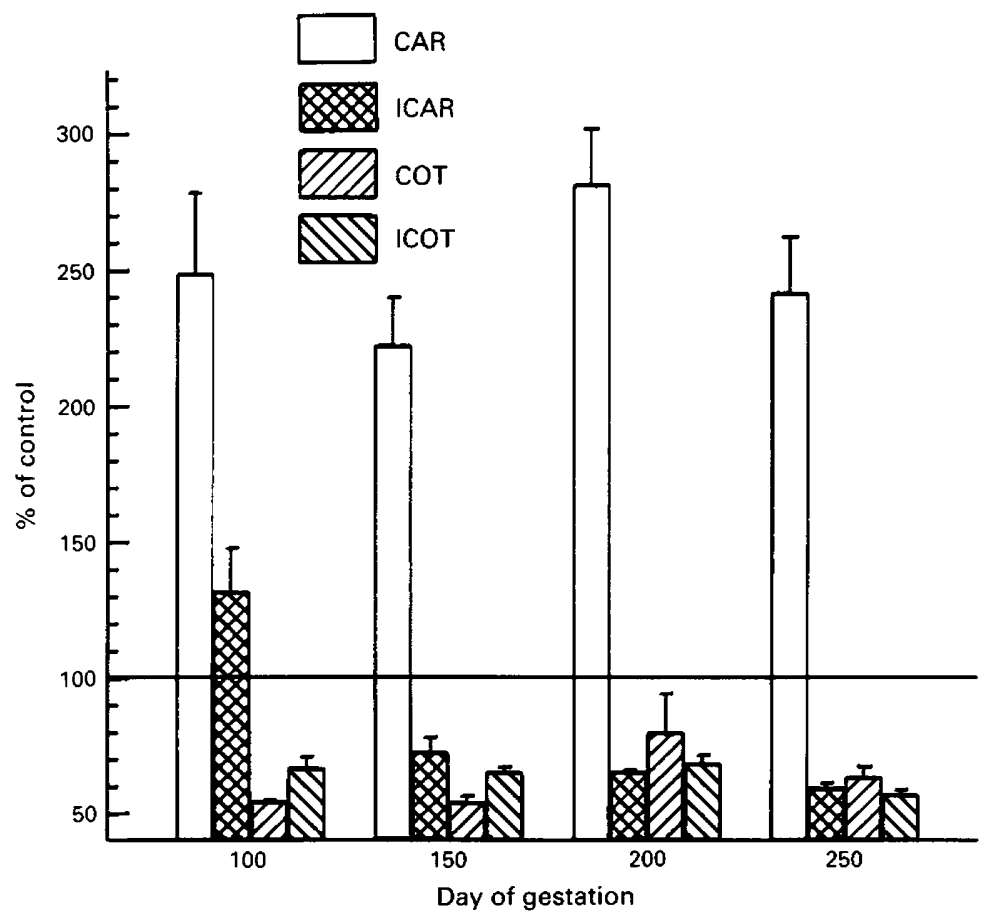

Fig. 1. Effects of media conditioned by bovine placental explants on proliferation of endothelial cells. CAR, cáruncular; ICAR, intercaruncular; COT, cotyledonary; and ICOT, intercotyledonary tissues. Values are means \pm s.e.m. (4-6 tissues per mean) as \% of control (unconditioned) media.

BAEC at all other stages of gestation (Fig. 1). Conditioned media from fetal cotyledonary and intercotyledonary placental tissues inhibited $(P<0.01)$ proliferation of BAEC at all stages and their activities did not change with stage of gestation (Fig. 1). Effects of conditioned media on proliferation of 3 T 3 cells did not vary with stage of gestation, and thus values for each tissue were averaged across gestation. Media conditioned by caruncular tissues were not mitogenic $(116 \pm 13 \%)$ whereas media conditioned by intercaruncular endometrium, cotyledon and intercotyledonary fetal membrane were mitogenic $(P<0.05)$ for 3T3 cells $(144 \pm 13,129 \pm 7$ and $142 \pm 2 \%$, respectively) compared with control (unconditioned) media.

Effects of explant-conditioned media on migration of BAEC also differed with stage of gestation $(P<0.01)$ and among tissues $(P<0.01)$, but no stage of gestation $\times$ tissue interaction was observed (Fig. 2). Migration-stimulating activities of conditioned media from all tissues increased $(P<0.01)$ from Days 100 to 200 and then decreased $(P<0.05)$. Conditioned media from caruncular tissues stimulated $(P<0.01)$ migration of BAEC on Days 150, 200 and 250 compared with unconditioned media (Fig. 2). Conditioned media from intercaruncular endometrium inhibited $(P<0.05)$ migration on Day 100 and stimulated $(P<0.05)$ migration on Day 200, whereas conditioned media from intercotyledonary tissues stimulated $(P<0.01)$ migration on Days 200 and 250 of gestation (Fig. 2). Media conditioned by cotyledon tissue inhibited $(P<0.01)$ migration of BAEC at all stages of gestation when compared with unconditioned media controls (Fig. 2).

Across all days of gestation, pools of caruncular-conditioned media exhibited angiogenic activity in fractions with $M_{\mathrm{r}}>10000,>30000$ and $>100000$ but not in fractions $<10000$, $<30000$ or $<100000$ (Table 1). Angiogenic activity of media conditioned by intercaruncular endometrium from Day 100 of gestation also seemed to be of $M_{\mathrm{r}}>100000$ (Table 1). 


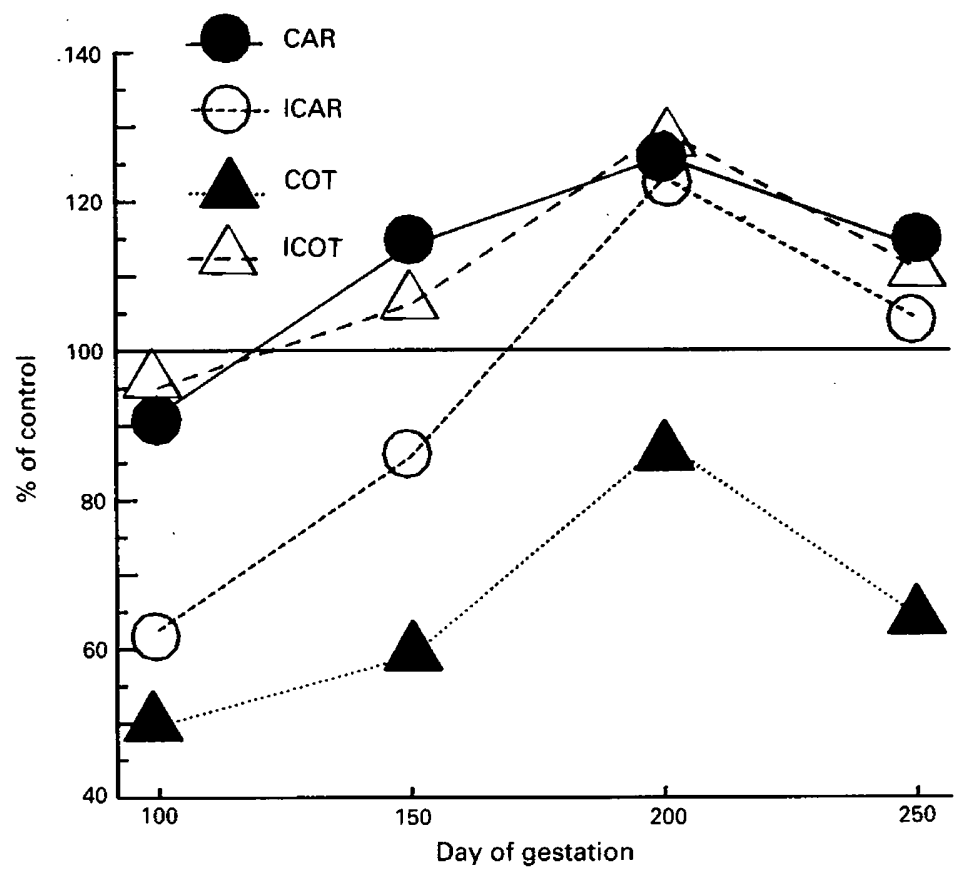

Fig. 2. Effects of media conditioned by bovine placental explants on migration of endothelial cells. CAR, caruncular; ICAR, intercaruncular; COT, cotyledonary; and ICOT, intercotyledonary tissues. Values are means (4-6 tissues per mean) as \% of control (unconditioned) media. Residual standard deviation (square root of mean square error) was $21.9 \%$.

Table 1. Effects of fractions of media conditioned by bovine placental explants on proliferation of endothelial cells

\begin{tabular}{lccccccc}
\hline & \multicolumn{7}{c}{ Molecular weight fractions $\left(\times 10^{-3}\right)$} \\
\cline { 2 - 7 } Tissue & Unfractionated & $<10$ & $>10$ & $<30$ & $>30$ & $<100$ & $>100$ \\
\hline CAR & $214 \pm 33$ & $92 \pm 4$ & $204 \pm 25$ & $91 \pm 2$ & $218 \pm 31$ & $96 \pm 4$ & $222 \pm 34$ \\
ICAR & $132 \pm 16$ & $93 \pm 2$ & $122 \pm 4$ & $89 \pm 7$ & $128 \pm 4$ & $92 \pm 1$ & $110 \pm 6$ \\
\hline
\end{tabular}

Values are means \pm s.e.m. as percentage of control (unconditioned) media. For caruncular (CAR) tissues, values are averages of 4 pools of media (4-6 cows per pool, one pool from each of Days 100, 150,200 and 250 of gestation); for intercaruncular (ICAR) tissues, values are for 1 pool of media ( 4 cows) from Day 100 of gestation.

\section{Discussion}

In the present study, media conditioned by bovine placental tissues were evaluated for their effects on two of the major components of angiogenesis: proliferation and migration of endothelial cells (Shepro \& D'Amore, 1984; Folkman \& Klagsburn, 1987). It has been proposed that these in-vitro bioassays provide an indication of factors which have direct effects on endothelial cells in vivo (Folkman \& Klagsburn, 1987). In previous studies of bovine placental tissues from mid-gestation, the presence of angiogenic activity in vitro was associated with ability to induce neovascularization in vivo of the chick chorioallantoic membrane (Reynolds et al., 1987b). Likewise, in evaluating angiogenic activity of bovine luteal tissues, Redmer et al. (1988) found close agreement between in-vitro and in-vivo bioassays. It seems reasonable to suggest, therefore, that angiogenic activities observed in the present study may be involved in regulating development of placental microvasculature in vivo. 
In agreement with our previous work in which mitogenic activity of bovine caruncular tissues from mid-gestation was of $M_{\mathrm{r}}>100000$ and heat labile (Reynolds et al., 1987b), mitogenic activity of caruncular tissue (all stages of gestation) and intercaruncular endometrium (Day 100) in the present study was of $M_{\mathrm{r}}>100000$. Caruncular and intercaruncular tissues of sheep from early pregnancy (Days 12-22 after mating) also secrete activity which is mitogenic for endothelial cells and in the same molecular weight range (unpublished observations). The tissues of cow and sheep maternal placenta therefore may secrete a similar angiogenic factor. Whether this factor resembles that reported for human placenta (Burgos, 1983; Buki \& Seppa, 1984) or the many angiogenic factors reported for other tissues (Folkman \& Klagsburn, 1987) remains to be determined. In the present study, media conditioned by bovine caruncular tissues were not mitogenic, whereas conditioned media from the other placental tissues were mitogenic for 3T 3 cells, which are an undifferentiated line of cells often used to assay for growth factors. The mitogenic effects of conditioned media on 3T3 cells therefore differed from their effects on endothelial cells. These results indicate either that bovine placental tissues secrete mitogenic activity which is specific for endothelial cells, or that endothelial cells and 3 T 3 cells respond differently to the same mitogen.

The fetal portion of the placentome (cotyledon) secreted activity that was inhibitory for both proliferation and migration of endothelial cells at all stages of gestation. Intercaruncular endometrium and intercotyledonary fetal membrane secreted activities which either inhibited or stimulated endothelial proliferation and migration, depending on the stage of gestation. It has been suggested that inhibitory as well as stimulatory factors are normally involved in microvascular development, and that an improper ratio of these factors may lead to rampant capillary growth, as observed in many pathological conditions (Denekamp, 1984; Folkman \& Klagsburn, 1987). Inhibitory activities secreted by maternal endometrial and fetal placental tissues may limit placental vascular development, thereby preventing rampant growth of placental capillaries. Control of placental vascular growth probably therefore involves a complex interaction between inhibitory and stimulatory mechanisms.

It has long been recognized that rapid growth of microvasculature is an important process in placental development (Hertig, 1935; Barcroft, 1946; Teasdale, 1976). In fact, placental endothelial cells appear to have a greater mitotic rate than endothelial cells of other tissues, including tumours (Denekamp, 1984). In the cow, caruncular vascular development continues throughout gestation (Hutchinson, 1962). Rates of uterine and umbilical blood flows also increase throughout gestation (Reynolds et al., 1986). In addition, rate of placental blood flow is an important determinant of the rate of transplacental exchange (Bell et al., 1986; Reynolds \& Ferrell, 1987). In the present study, caruncular tissues secreted activity that stimulated proliferation of endothelial cells at all stages, and migration of endothelial cells from Days 150 to 250 of gestation. These stimulatory activities secreted by caruncular tissues probably support continued growth of placental microvasculature and thereby ensure an adequate placental blood supply for rapid fetal growth during late gestation. Effects of all placental tissues on migration of endothelial cells became more positive later in gestation, which also may enhance placental vascular growth.

The present paper and also a previous report (Reynolds et al., 1987b) indicate that stimulatory angiogenic activity is produced primarily by maternal placental tissues. By using various techniques (e.g. reciprocal matings or embryo transfers between breeds), it has been shown that the maternal genotype has a profound influence on fetal growth (Walton \& Hammond, 1938; Venge, 1950; Hunter, 1956; Joubert \& Hammond, 1958). In addition, the maternal system appears to have a limited ability to support fetal growth (Barcroft, 1946; McKeown \& Record, 1953; Alexander, 1964; Anderson et al., 1978). Production of angiogenic activity by the maternal placenta may have an important role in regulating placental vascular development and therefore may be a primary determinant of the ability of the uterus to support fetal growth.

We thank J. D. Kirsch, K. C. Kraft and D. S. Millaway for expert technical assistance. Journal Article No. 1608 of the North Dakota Agricultural Experiment Station; Projects ND1780 and 
ND1782. Supported, in part, by grants from the National Science Foundation (RII8610675) and Public Health Service (HD22559).

\section{References}

Alexander, G. (1964) Studies on the placenta of the sheep. Placental size. J. Reprod. Fert. 7, 289-305.

Anderson, G.B., Cupps, P.T., Drost, M., Horton, M.B. \& Wright, R.W., Jr (1978) Induction of twinning in beef heifers by bilateral embryo transfer. J. Anim. Sci. 46, 449-452.

Barcroft, J. (1946) Researches on Pre-natal Life. Thomas, Springfield.

Bell, A.W., Kennaugh, J.M., Battaglia, F.C., Makowski, E.L. \& Meschia, G. (1986) Metabolic and circulatory studies of fetal lamb at midgestation. Am. J. Physiol. 250, E538-E544.

Buki, K. \& Seppa, H. (1984) A low-M, chemoattractant for vascular endothelial cells. FEBS Letters 184, $254-258$.

Burgos, H. (1983) Angiogenic and growth factors in human amnio-chorion and placenta. Eur. J. clin. Invest. 13, 289-296.

Denekamp, J. (1984) Vasculature as a target for tumour therapy. In Progress in Applied Microcirculation, Vol. 4, pp. 28-38. Eds F. Hammersen \& O. Hudlicka. Karger, Basel.

Fahmy, M.H., Holtman, W.B., Macintyre, T.M. \& Moxley, J.E. (1978) Evaluation of piglet mortality in 23 two-breed crosses among eight breeds of pigs. Anim. Prod. 26, 277-285.

Ferrell, C.L. \& Reynolds, L.P. (1987) Blood flow and nutrient uptake of the gravid uterus, fetus and uteroplacenta of Hereford or Charolais cows bearing single or twin fetuses. J. Anim. Sci. 65 (Suppl. 1), 148.

Folkman, J. \& Klagsburn, M. (1987) Angiogenic factors. Science, N.Y. 235, 442-447.

Fuchs, A., Lindenbaum, E. \& Marcoudas, N.G. (1985) Location of the angiogenic activity in the pregnant human uterus. Acta anat. 124, 241-244.

Hertig, A.T. (1935) Angiogenesis in the early human chorion and in the primary placenta of the Macaque monkey. Contrib. Embryol. Carnegie Instn 146, 39-91.

Hufiman, E.M., Kirk, J.H. \& Pappaioanou, M. (1985) Factors associated with neonatal lamb mortality. Theriogenology 24, 163-171.

Hunter, G.L. (1956) The maternal influence on size in sheep. J. agric. Sci., Camb. 48, 36-60.

Hutchinson, L.R. (1962) The hemodynamics of the isolated pregnant uterus of the cow (Bos taurus). M.S. thesis, Iowa State University, Ames.

Joubert, D.M. \& Hammond, J. (1958) A crossbreeding experiment with cattle with special reference to the maternal effect in South Devon-Dexter crosses. $J$. agric. Sci., Camb. 51, 325-341.

Kirk, R.E. (1968) Experimental Design: Procedures for the Behavioral Sciences. Wadsworth, Belmont.

Mckeown, T. \& Record, R.G. (1953) The influence of placental size on foetal growth in man, with special reference to multiple pregnancy. J. Endocr. 9, 418-426.

Morriss, F.H., Rosenfeld, C.R., Crandell, S.S. \& Adcock, E.W., III (1980) Effects of fasting on uterine blood flow and substrate uptake in sheep. J. Nutr. 110, 2433-2443.
Mossman, H.W. (1937) Comparative morphogenesis of the fetal membranes and accessory uterine structures. Contrib. Embryol. Carnegie Instn 26, 128-246.

Record, R.G., Gibson, J.T. \& McKeown, T. (1952) Foetal and infant mortality in multiple pregnancy. $J$. Obstet. Gynaecol. Br. Emp. 59, 471-482.

Redmer, D.A., Grazul, A.T., Kirsch, J.D. \& Reynolds, L.P. (1988) Angiogenic activity of bovine corpora lutea at several stages of luteal development. $J$. Reprod. Fert. 82, 627-634.

Reynolds, L.P. \& Ferrell, C.L. (1987) Transplacental clearance and blood flows of bovine gravid uterus at several stages of gestation. Am. J. Physiol. 253, R735-R739.

Reynolds, L.P., Ferrell, C.L., Nienaber, J.A. \& Ford, S.P. (1985a) Effects of chronic environmental heat stress on blood flow and nutrient uptake of the gravid bovine uterus and foetus. J. agric. Sci., Camb. 104, 289-297.

Reynolds, L.P., Ford, S.P. \& Ferrell, C.L. (1985b) Blood flow and steroid and nutrient uptake of the gravid uterus and fetus of sows. J. Anim. Sci. 61, 968-974.

Reynolds, L.P., Ferrell, C.L., Robertson, D.A. \& Ford, S.P. (1986) Metabolism of the gravid uterus, foetus and utero-placenta at several stages of gestation in cows. J. agric. Sci., Camb. 106, 437-444.

Reynolds, L.P., Infeld, J.E., Anthony, R.V., Keisler, D.H. \& Redmer, D.A. (1987a) In vitro secretion of ovine placental factor that stimulates endothelial cell mitogenesis. J. Anim. Sci. 65 (Suppl. 1), 148, Abstr.

Reynolds, L.P., Millaway, D.S., Kirsch, J.D., Infeld, J.E. \& Redmer, D.A. (1987b) Angiogenic activity of placental tissues of cows. J. Reprod. Fert. 81, 233-240.

SAS User's Guide (1985) Statistics, 5th edn. Statistical Analysis System Institute, Cary, NC.

Shepro, D. \& D'Amore, P.A. (1984) Physiology and biochemistry of the vascular wall endothelium. In Handbook of Physiology, Section 2, Vol. IV, Part 1, pp. 103-164. Eds. E.M. Renkin \& C.C. Michel. American Physiological Society, Washington, DC.

Steel, R.G.D. \& Torrie, J.H. (1960) Principles and Procedures of Statistics. McGraw-Hill, New York.

Teasdale, F. (1976) Numerical density of nuclei in the sheep placenta. Anat. Rec. 185, 187-196.

Venge, $\mathbf{O}$. (1950) Studies of the maternal influence on birth weight in rabbits. Acta zool. 31, 1-148.

Walton, A. \& Hammond, J. (1938) The maternal effects on growth and conformation in Shire horse-Shetland pony crosses. Proc. R. Soc. B 125, 311-335.

Wootton, R., McFayden, I.R. \& Cooper, J.E. (1977) Measurement of placental blood flow in the pig and its relation to placental and fetal weight. Biol. Neonate 31, 333-339. 